\title{
Implementation of the Convention on the Rights of the Child in China: Regulation the Child Abuse in Schools
}

\author{
Peng Xu
}

\begin{abstract}
Child abuse occurring outside the home in China is inflicted on school-age children and can result in serious physical and mental harm. China is a developing country with a population of over 1.2 billion, of whom over 300 million are children under the age of 16 . Making a commitment to respect the rights of children has profound implications for the status of children in China. The Convention on the Rights of the Child (hereinafter CRC) requires that State Parties take all appropriate measures to protect child from abuse. China has ratified the CRC at domestic level and taken legislative, judicial and other measures to prevent children from abuse. Examination of the child abuse statutes and judicial practice of China reveals that China's domestic law has failed to provide adequate protection for children. Chinese traditional Confucian culture and deficiency of CRC both contribute to the soaring number of incidents of child abuse in schools. It is suggested that China review its legislation, establish the independent human rights commission, raise awareness of children's rights and improve cooperation with NGOs to ensure that it conforms fully with the requirements of the CRC.
\end{abstract}

Index Terms - Child abuse in schools, implementation of CRC, China's regulation.

\section{INTRODUCTION}

Child maltreatment has a long history in Chinese society. In recent years, child abuse occurring outside the home, in particular maltreatment in the primary school or kindergarten has attracted increasing attention in mainland China (hereinafter China).

There have been many incidents of classroom violence against children in recent years. Unfortunately, such stories are not the result of occasional human errors that are bound to occur in any public agency. Instead, they are inevitable and frequent outcomes stemming from the flawed founding premises and the weak legal system.

This article first explores the prevalence of child abuse in Chinese school, and analyzes recent surveys of child abuse conducted in various Chinese communities. Second, this article presents the provisions of CRC related to child abuse and the implementation requirements of the convention. Next this article analyzes China's implementation of CRC and the major problems in implementation of China. Finally, this article argues that China fails to do enough to protect children against abuse, and provides some implementation suggestions.

Manuscript received May 14, 2013; revised July 25, 2013.

Peng $\mathrm{Xu}$ is with the Law School, WuHan University, Hubei Province, China (e-mail: whxp123@ hotmail.com).

\section{Prevalence of Child Abuse in Chinese Schools}

Despite the overwhelming research on child abuse in China, there are still very few studies that have examined child abuse in classroom. The 2005 survey looked at 484 Chinese students in Hebei Province and found that $53 \%$ had experienced non-contact (i.e. not being beaten or hit by hand or objects) punishment by their teachers at least once before the age of 16. This survey also noted that the students reported having been punished by being forced to run, to do homework, to stand, to kneel down, to not eat or to suffer the cold in the winter. The 2006 survey about 5141 middle school students in Anhui Province shows that $5.3 \%$ of them experienced physical contact and/or sexual abuse and $24.5 \%$ students experienced non-physical contact sexual abuse (i.e. verbal sexual harassment, exhibitionism, or emotional incest, not involving genital contact). Studies in the review showed that children are also increasingly vulnerable to abuse by peers and 'friends'. In the 2009 survey that looked at 1.200 students in the city of Xi'an, $32.1 \%$ of them reported experiencing corporal punishment by teachers [1].

These statistics reveal that, child maltreatment is a pervasive problem in Chinese society. Also, of the four categories of maltreatment, physical abuse at Chinese school is significantly higher than the other types. In order to provide a more in-depth discussion of the problem, I will focus on physical abuse at schools.

\section{ChILd Abuse PREVEnTION AND THE CRC}

The CRC is the most comprehensive document on the rights of children; it delineates the notion of special protection seen throughout international law [2]. The general protection against abuse is established in Article 19 of the CRC. This article requires the state to "take all appropriate legislative, administrative, social and educational measures to protect the child from all forms of physical or mental violence, injury or abuse, neglect or negligent treatment, maltreatment or exploitation, including sexual abuse, while in the care of parent(s), legal guardian(s) or any other person who has the care of the child," In pursuit of this goal, "such protective measures should, as appropriate, include effective procedures for the establishment of social programs to provide necessary support for the child and for those who have the care of the child, as well as for other forms of prevention and for identification, reporting, referral, investigation, treatment and follow-up of instances of child maltreatment described heretofore, and, as appropriate, for judicial involvement."

Article 28(2) requires states to "take all appropriate 
measures to ensure that school discipline is administered in a manner consistent with the child's human dignity and in conformity with the present Convention;" Article 34, drafted to curtail this world-wide problem, declares that "States Parties undertake to protect the child from all forms of sexual exploitation and sexual abuse;" And Article 37(a) provides that, "...no child shall be subjected to torture or other cruel, inhuman or degrading treatment or punishment. Neither capital punishment nor life imprisonment without possibility of release shall be imposed for offences committed by persons below 18 years of age."

\section{IMPLEMENTATION OF CRC IN CHINA}

Chinese government has signed and ratified the CRC and it came in effect on April 1, 1992. When China ratified the Children's Convention it agreed to respect and ensures the rights in the CRC. Legislation and legal enforcement through courts are the key measures for implementation of CRC.

\section{A. China's Laws on Child Abuse}

China declares that it protects a wide range of children's rights through domestic legislation and by ratifying and joining the relevant international treaties. Certain laws and regulations dealing with child abuse have already been enacted. Article 49 of the Constitution of PRC 1982(hereinafter "Constitution Law") states that "Maltreatment of old people, women and children is prohibited." Article 8(5) of the Teachers Law of the People's Republic of China(hereinafter "Teachers Law") states that teachers should "stop acts that are harmful to students and other acts that encroach upon students' legitimate rights and interests, criticize and combat the phenomena that impair the sound growth of students." Article 21 of the PRC Law on the Protection of Minors (revised in 2006, hereinafter Minors Law) states that "The teaching and administrative staff in schools, kindergartens and nurseries shall respect the personality and dignity of minors, and may not commit corporal punishment either directly or in disguised forms against minors, or commit any other act that humiliates the personality and dignity of minors." Article 29 of the Compulsory Education Law of the People's Republic of China (revised in 2006) provides that "teachers shall respect the personality of students, and they shall not discriminate against students, punish them physically or in disguised form, or humiliate them or strip them of their dignity, nor shall they infringe on the students' legitimate rights and interests."

In 2003, the Supreme People's Court stipulated in its Interpretation of Certain Problems Regarding the Application of the Law in the Hearing of Compensation Cases Involving Bodily Harm, that "if an educational institution such as a school has not fulfilled its obligations within the scope of its duties such that a minor suffers bodily harm, it shall bear liability for the corresponding compensation."

\section{B. Judicial Remedies}

Where the abuse is reported, China makes active use of judicial intervention in regard to acts of school or domestic violence. Many local police stations have set up "domestic violence reporting points" which, when they receive a request for help, respond as quickly as possible in order to put a timely stop to the violence taking place. "Personal safety protection orders" are issued to protect children and women at risk from family violence in circumstances where the police have reasonable grounds to believe that family violence has or may occur. The Regulations on Legal Aid passed by the State Council in July 2003 provide that "legal aid is the government's responsibility." Accordingly, at the local level, provinces and municipalities have enacted corresponding regulations. Also, the Minors Law requires the judiciary to protect minors' legal rights during judicial proceedings. By the end of 2008, 2,219 youth courts of various types had been set up nationwide, with 419 independent young offenders' courts and over 7,000 full-time or part-time youth court judges [3].

\section{School-Based Programs to Prevent Child Abuse}

In order to prevent and combat violence against children, Chinese government has developed several programs. China, in line with her own national situation, promulgated the National programmer of Action for Child Development in China (2001-2010) (2011-2020) (hereinafter as the Program of Action). They are the significant national plans of action that centered on the child and on promotion of child development. It is noted that the implementation of the Programs has remarkable impact on the improvements in the environment and conditions necessary for children's survival, protection and development. Children's rights have been further protected and major achievements have been made in children's development.

What's more, the Outline of the 12th Five-Year Plan on Economic and Social Development(approved in 2011), makes clear that the government will "implement the Children's Development Programmer, safeguarding children's rights to survival, development, protection and participation in accordance with the law, improving the environment in which children grow up, and promoting their healthy mental and physical development." In 2006, China, in cooperation with UNICEF, launched a Child Protection System and Network development project, which ran for the 2006-2010 cycle. In pilot communities in six cities including Nanjing and Shijiazhuang, training and publicity activities were launched, and complaints hotlines were set up for reporting violence against children.

It is worth mentioning that China has initiated medical relief and appraisal work in regard to victims of violence. Numerous provinces and municipalities have established centers for appraisal of injuries from domestic violence, and many hospitals have become interventional hospitals against domestic violence, where victims' case histories can directly be used as evidence.

\section{NGO Involvement in Child Protection}

There are a number of non-governmental organizations whose main objective is to facilitate the improved protection of children in its broadest sense in China. All-China Women's Federation and its branches have initiated programs to promote the implementation of national programs on women and children's development, and to safeguard their legitimate rights and interests; the Chinese 
People's National Committee for the Defence of Children, Which receives input from areas such as health, education, science, art, literature, law, sports, social welfare, religion, nationality, feminists, youth, and trade unions; China Children and Teenagers' Foundation, which provides support for caring, fostering and educating children and teenagers in China; China Youth Development Foundation, which devotes itself to the wellbeing and development of Chinese youth, primarily with regards to education, health, environmental protection, volunteerism and engagement.

NGOs have been offering comprehensive services for vulnerable children in a way that is more independent of the state. In January 2006, Xi'an Abuse Prevention and Treatment Centre for Children, a non-governmental organization, were established, with a comprehensive rescue and assistance system. This Centre provides treatment and care for children who have suffered physical abuse, sexual abuse and harm to their health as a result of negligence of care.

\section{MAJoy PRoBlems In IMPLEMENTING CRC IN CHINA}

\section{A. The Gap between CRC and China's Law}

China has constitutional and statutory provisions outlining programs of protective services for children; however, there are numerous areas where gaps remain.

Firstly, there are no reporting mandates in China's law. Reporting to the state department of education would increase accountability of the agencies involved because the state department of education would be one more agency to help ensure an accused teacher does not continue to abuse other students in a new school [4]. According to the Teachers Law, teachers have the obligation "not to violate the student's legitimate rights and interests." But school staffs are not obliged to report child abuse by law.

Allowing teachers to use their discretion puts children at risk. Under the Teachers Law, any teacher who imposes corporal punishments on students and refuses to mend their way after being reprimanded shall be "given administrative sanctions or dismissed by their schools, other institutions of education or administrative departments of education." The underlying assumption of the law is that these provisions will be applied through administrative means, but there are no consequences for failure to do so [5]. On the other hand, child abuse is often treated as a threat to school's reputation. Facing increasing pressure to hit targets and maintain student roll numbers, schools are reluctant to report allegations of abuse.

Secondly, penalties for child abuse at schools are vacancy in criminal law. It is worthwhile to note that punishment has been mandated by the Criminal Law of PRC (revised in 1997, hereinafter "Criminal Law") for cases of severe maltreatment by one member of a family toward another. There is no indication; however, this prescription also applies equally to a teacher or non-family member. Furthermore, the Criminal Law stipulates that the victims of child abuse should initiate a lawsuit themselves, ignoring it is impossible for most children to do that. Thus most offenders will be exempt from punishment unless the abuse causes grave injury or death (in such case, the offenders could be charged with intentional injury or manslaughter). The lack of penalties for child abuse at schools can't be taken as compliance with the best interests of the child.

\section{B. Ineffective and Undesirable Judicial Remedies}

In China, compensations are now serving an ever-increasing number of child abuse victims with larger amounts of benefits than ever before. But not all mental injuries are awarded compensation. General Principles of the Civil Law of People's Republic of China(revised in 1986) simply state that "a plaintiff may demand compensation for both physical injury and mental injury(including Infringement upon one's right of personal name, portrait, reputation or honors)". The Judicial Interpretation of Compensation for Mental Injury (issued by the Supreme People's Court in 2001) states that "if no serious outcome occurred, the court shall not accept the victim's claim for compensation of mental damage." Namely, in case when serious consequences have been caused, the court may award "soothing money" for mental injury to victim at his request. While in cases involving less serious bodily harm, neglect or emotional abuse independently, the claim is usually dismissed. Even if victims suffering from mental injury may get compensated as a consequence of obvious physical injury, they often receive little compensation for damages under the current compensation law. Compensation laws fail to provide adequate compensation for child abuse victims, leaving them more vulnerable.

Moreover, procedures pertaining to the presentation and investigation of children's complaints of abuse are of doubtful effectiveness. For example, Article 51 of the Minors Law requires "trial of cases without delay where a minor's lawful rights and interests are infringed upon." However, no specific time limit is established by law about hearing the case. This article also requires the legal aid institutions or the courts to provide legal aid to the minors, which in practice is not yet fulfilled.

\section{Absence of Independent National Human Rights Institution}

The relevant departments of China's legislative, judicial and administrative branches and various social organizations have put mechanisms in place. Among these, the State Council Working Committee on Women and Children functions as the interdepartmental coordinating body for work concerning women and children, and plays a leading role in protecting the rights and interests of children and coordinating children's affairs. But it is not an independent national human rights institution. Independence is crucial to the national human rights commission, which is a precondition for the institution to conduct the work of human rights protection. Although human rights NGOs may act independently from government, Chinese laws and regulations have not fully endorsed NGOs or all activities conducted by NGOs. At present, Chinese NGOs can only see the result of policies; they cannot see the process of policy-making [6]. The space in which NGOs may operate and the scope of their activities remains very limited. 


\section{REASONS FOR OBSTACLES FACING CHINA'S IMPLEMENTATION OF CRC}

\section{A. Impact of Confucianism on Child Abuse}

From a cross-cultural perspective, child abuse is inherently embedded within a broader social and cultural context, which shapes the ideas and behavior of both parents and children [7]. In China, Confucianism is one of the dominant influences at the ideological, philosophical, and personal level [8]. This influence is also prevalent in China's cultural disposition toward child abuse.

Confucianism states that parents own their children from birth, and thus, children's obedience and duties to their parents are unconditional [9]. The hierarchy between teachers and students within the classroom, analogous to the hierarchy between parents and their offspring, creates teacher-student relationships that discourage students from questioning the teacher's disciplining or instructional authority [10].

In China, it is widely believed that discipline is required for students in order for them to be successful in education, especially during the compulsory education period. The "goals" of maltreatment are considered as ultimately benefiting the child and family, and so have been used to excuse or justify maltreatment as a tolerated, if not accepted practice [11].

However, research has consistently shown that corporal punishment rarely motivates children to act differently, because it does not bring an understanding of what they ought to be doing, nor does it offer any kind of reward for being good [12].

\section{B. Deficiency of $C R C$}

The CRC does not impose specific obligation on State Parties, rather, it requires states to undertake "all propriate measures for the implementation and protection of rights mentioned in the Convention," which leaves discretionary power to the State Parties.

In addition, the CRC does not include coercive measures such as international investigations of human rights violations, enforcement of the Convention through domestic legal processes, or imposition of collateral consequences for failure to comply. As such, if China refuse to comply with the Convention, either in word or deed, there is very little in the text of the Convention that can be used to force them to do so[13].

\section{RECOMMENDATIONS}

In summary, there still exist challenges in China's whole series of processes from legislation to policy decisions and adoption of concrete measures for effective implementation of CRC. Full implementation of the CRC must therefore be accorded a high priority for national legislation and other measures.

\section{A. Filling the Gap between the CRC and Domestic Law}

The Committee recommends that "China continue to review and update legislation to ensure that it conforms fully to the principles and provisions of the Convention." Specifically, mandatory reporting requirements must be incorporated into the China's legal infrastructure, and the Criminal Law should be revised to include the offense of child abuse. Second, Chinese legislature should take action to relax compensability thresholds for mental injury claims. Courts should allow mental anguish damages to be recovered in full and this can be done by interpreting the "serious outcome" concept broadly to include "pure mental anguish". Finally, there is a need to adopt the procedures for the effective implementation of the laws and regulations with regard to the judicial protection.

\section{B. Establishing the Independent Human Rights Commission}

Independent national human rights institutions are an important mechanism to promote and ensure the implementation of the CRC. The Commission has repeatedly called for the establishment of national human rights institutions, underlining the important role independent national human rights institutions play in promoting and protecting human rights and enhancing public awareness of those rights. Some experts and scholars believe that an independent human rights commission should be established in China, in accordance with internationally recognized standards to monitor human rights violations and promote the public's human rights awareness.

As the Committee pointed out in the No.2 general comment(2002) of the Committee on independent national human rights institutions, such human rights institutions should be authorized to accept, investigate and handle complaints from the public, including complaints from individual children and be capable to provide sufficient funds, human resources and materials. It would be ideal to modify the Constitution Law by stipulating establishing a national human rights institution in the Constitution Law and then formulate separate laws to make detailed stipulations on various affairs related to the establishment of the institution.

\section{Raising Awareness of Children's Rights}

It is extremely important that children's rights awareness raising challenges social acceptance of corporal punishment within schools. Unconditional and unreciprocated respect is not conducive to basic human rights values where each person's dignity and worth is of equal weight. Some national programs provide a framework for child protection in China, but there is no clearly defined school advocacy program designed to encourage students to refer suspected abuse cases, school children who suffer abuse in the schools are often unable to find effective help.

It is recommended that reforms should be carried out in all educational systems, especially in early childhood education, to ensure children's health and safety. Thus, the government should make sure that the rights in the CRC are known and understood by all children by integrating the $\mathrm{CRC}$ into the school curriculum. But teachers are not alone in their responsibility to promote understanding about the meaning and provisions of human rights. Education department and other organisations that work for and with children and young people should support their staff to 
understand the importance of children's rights and their application to their work.

\section{A. Improving Cooperation with NGOs}

The majority of Chinese NGOs are either government-organized NGOs or quasi-official NGOs, while individual-organized NGOs and international NGOs are relatively less influential. Although NGOs and government sometimes worked together in the establishment of new treaties and organizations, the activities of Chinese NGOs involved in legal reform is limited. On the other hand, Chinese NGOs manage to bypass the government's restrictions in one way or another. For example, most NGOs possess better information than most government representatives or officials, but they seldom share the information with the government agencies.

Therefore, Chinese government should facilitate and encourage the independence and expansion of activities by non-governmental organizations, in particular those working for the promotion and protection of child rights, inter alia, by ensuring their free and active involvement in the implementation of the CRC, including in the preparation of reports and the implementation of the Committee's concluding observations and recommendations.

\section{REFERENCE}

[1] Child Maltreatment: Prevalence, Incidence and Consequences in the East Asia and Pacific Region, A Systematic Review of Reasearch, UNICEF East Asia and Pacific Regional Office, 2012, pp. 43.

[2] A. Farmer and K. Stinson, "Failing the grade: How the use of corporal punishment in U.S. public schools demonstrates the need for U.S. ratification of the children's rights convention and the convention on the rights of persons with disabilities," New York Law School Law Review, vol. 54, pp. 1044, 2009/2010.

[3] Consideration of Reports Submitted by States Parties under Article 44 of the Convention, "Third and Fourth Periodic Reports of States Parties due in 2009, China," 2012, CRC/C/CHN/3-4, para195, pp. 42.

[4] K. J. Krogman, "Protecting our children: reforming statutory provisions to address reporting, investigating, and disclosing sexual abuse in public schools," Michigan State Law Review, vol. 1605, pp. $1648,2011$.
[5] S. Woodman, "Human rights as 'foreign affairs: China's reporting under human rights treaties," Sweet \& Maxwell Asia, vol. 35, no. 1, pp. 199, Aug. 2005.

[6] F. Gradijan, "Dispute resolution and power project permitting in China," Texas Journal of Oil, Gas and Energy Law, vol. 5, pp. 367 , Feb. 2010.

[7] Y. H. Zhu and K-L. Tang. (Dec 2011). Physical child abuses in urban china: victims' perceptions of the problem and impediments to help-seeking. International Social Work. [Online]. 55(4). pp. 2 Available: http://isw.sagepub.com/content/55/4/574

[8] J. Zhao and M. Hu, "A comparative study of the legal education system in the United States and china and the reform of legal education in china," Suffolk Transnational Law Review, vol. 35, pp. 331, Jun 2012

[9] F. H. Zhai and Q. Gao, "Child Maltreatment among Asian Americans characteristics and explanatory framework," Child Maltreatment, vol. 14, pp. 213, May 2009

[10] A. Mamatey, "South Korean EFL teachers' perceptions of corporal punishment in school: Cultural vs. educational system," Novitas-ROYAL, Research on Youth and Language, vol. 4, no. 2, pp 191, Oct. 2010.

[11] M. L. Liao, A. S. Lee, A. C. Roberts-Lewis, J. S. Hong, and K. S. Jiao, "Child maltreatment in China: An ecological review of the literature," Children and Youth Services Review, vol. 33, pp. 1709, Sep. 2011.

[12] Ending Corporal Punishment of Children in South Africa, Save the Children: Regional Office for Southern Africa, Save the Children Sweden, 2005, pp. 22.

[13] V. T. Hernandez, "Making good on the promise of international law: the convention on the rights of persons with disabilities and inclusive education in China and India," Pacific Rim Law and Policy Journal, vol. 17 , no. 2 , pp. 520 , Mar. 2008.

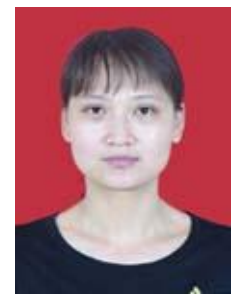

Peng Xu was born in Jiangxi Province, China on October 29, 1972. From 1991 to 1995 , Faculty of Foreign Language at Shangrao Normal University, Jiangxi, China; From 2004 to 2007, Master in Economic Law at Law School in Jiangxi University of Finace and Economics. She is currently studying in the 3th year of PhD at the Law School in Wuhan University, Hubei, China. Ms. $\mathrm{Xu}$ is also an associate professor at Economic Crime Investigation in Jiangxi Police College, Jiangxi, China, and the editor of International Law Review of Wuhan University. Research interests: human rights, international criminal law, international organization. 